\title{
MAJOR ISSUES AND CHALLENGES OF HUMAN AND SOCIETAL DEVELOPMENT
}

\author{
Hasan Askari Rizvi*
}

\begin{abstract}
The role of state in the contemporary global system is greatly shaped by its inner or domestic strength that include economic resilience, socio-political harmony and a stable constitutional political order. These attributes cannot be achieved by a state unless it assigns the highest priority to human and societal development and promotion of egalitarian socio-economic arrangements that provide equal opportunities to all citizens irrespective of ethnicity, language, religion, caste, region or gender. The focus is on transforming human resources into human capital through education, learning of technology and skills, and health care. There is now a greater emphasis on good governance and a fair and transparent political management and delivery of basic services to the society. This covers policy making and implementation regarding a host of key issues. It is also important to ensure that the fruits of economic growth are fairly distributed in the society. The state must work towards removing socio-economic inequities and disparities among people and regions. This paper examines the major factors responsible for the growing emphasis in state policy on human and social development as well as the historical evolution of this change. It is argued that the political developments in the 1990s and later contributed most in creating a global awareness about human and societal developments. These include, inter alia, the end of the Cold War, the collapse of some states, the rise of religious and cultural extremism and terrorism and the efforts of the various organs and agencies of the United Nations to promote human development and social stability. The paper also identifies the major obstacles in the developing countries, especially in Pakistan, to socio-economic development and distributive justice.
\end{abstract}

Keywords: Social and human development, UN, UNDP, HDI, MDGs, SDGs, NAM, postCold War period

\section{Introduction}

The end of the Cold War (1990) and the collapse of the Soviet Union (1991) enabled the United States and other Western states to rearticulate their role in shaping the nature and direction of the global system. The primary drivers of the global system changed and the pre-requisites for an active role by a state in the global system were reformulated.

However, by the end of the first decade of the $21^{\text {st }}$ century, the primacy of the West in the global system was questioned not simply because of the inability of the West to continue commanding the global system but also due to the rise of other states in global affairs. The unipolar system that developed in the immediate aftermath of the collapse of the

* Hasan Askari Rizvi, Ph.D. Professor Emeritus, University of the Punjab, Lahore, Pakistan 
Soviet Union was transformed into competitive multi-polarity; multiple power centres emerged that mattered in shaping the politics of different regions. This in turn enhanced their global role.

The U.S. continues to be the strongest military power and one of the leading economies of the world. Nevertheless, its capacity to successfully project its military power in the global system depends on its ability to mobilize other global and regional states in its favour or at least defuse their opposition. There are no straight lines of "friendship" and "rivalry". The interaction among the states is issue-oriented. The same state can work together with another state one issue and diverge in another. The balancing of positive and negative interaction calls for astute diplomacy and a deep understanding of the changing dynamics of international and regional politics.

Russia is now showing strong signs of resurgence as a global player by being more assertive in protecting its interests in the states on its border against the efforts of the NATO and the European states to make inroads there. It is also taking more interest in other regions, especially in the conflict ridden Middle East. China is now a more confident power, working on building a global network of roads and sea routes for trade and economic relations with all continents. There is a talk of the Chinese Century ${ }^{1}$, coupled with its focus on Asia-Pacific region for security and economic considerations that brings it in conflict with the US and some other states of the region. However, the US-China economic ties, including trade and investment, are strong enough to dissuade the two sides to view the political and security situation in Asia-Pacific region and elsewhere in zero-sum terms.

Another important change in the global system is the growing role of transnational violent or terrorist groups that challenge the notion of the primacy of the state and the global order. These extremist and terrorist groups build support through ideological mobilization and excessive and ruthless use of violence. The most powerful states like the US, China and Russia are as much threatened by these groups as are small and weak states. Security against such groups has also become a major concern of individual states and the global system.

Still another significant change is that hard military power is no longer viewed as the major instrument for enhancing one's diplomatic clout. Non-military instruments of power and influence are also emphasized for cultivating and sustaining influence. This includes the condition of the economy of a state, human capital development, socioeconomic progress, societal conflict or harmony, and official and non-official diplomacy. The hard military power has to be supplemented with the soft or non-military power, and, at times, the latter is preferred over the former. There is now more emphasis on economic interaction and trade under the rubric of globalization that emphasizes the movement of people, ideas, goods and services across the territorial boundaries of the states.

\footnotetext{
${ }^{1}$ For a discussion of the China Century and its implications for the United States, see Michael Beckley, “China's Century," International Security (Vol.36 No.3, Winter 2011-12), pp.41-78.
} 
The major economies of the world faced an acute economic crisis in 2007-2008, which confronted these economies with recession and loss of jobs. Some of these economies struggled hard to protect them from the negative impact of the global financial crisis. It all started in the United States in 2007-2008 when the housing market crashed and a large number of house-owners were unable to fulfill the financial obligation of their housing mortgages. The mortgage default caused a severe financial crisis for various leading financial institutions, especially the banks. With the collapse of the investment Bank, Lehman Brothers, in September 2008, a financial crisis engulfed the U.S., along with European countries, Australia, Japan and some East Asian countries along with crisis. The U.S. Treasury pumped in funds as a bail-out package and it was in 2009 that the global financial crisis became manageable. However, this financial crisis did not upset the overall power dynamics of the global system, which continued to be characterized by the U.S. primacy, slow rise of other nations, an emphasis on human development issues against the backdrop of the challenge of global terrorism.

\section{Greater Emphasis on Internal Strength of the State}

The above-mentioned developments have changed the factors and conditions that strengthen or weaken the role of the state in regional and global affairs. These are not entirely new factors but draw more attention in the discussion of the capacity of the states to address their internal, regional and global issues and problems.

There is a greater emphasis on democracy, human rights and human dignity, human development, socio-economic equity, environmental issues and greater freedom for economic activity, trade and investment. All measures for economic development and industrial and agricultural growth must also ensure that their gains are fairly distributed in the society and that acute socio-economic inequities are prevented A state's role at the regional and global level is determined by domestic strength with reference to three issues that include socio-political harmony, economic resilience coupled with distributive justice and the state institutions and processes enjoying voluntary loyalty of populace. If the state performs successfully on these three counts, it has greater potential to become an effective player at international level and/or successfully withstand external pressure.

Greater attention is given to internal strengths and weaknesses of states because the security of state is not merely threatened by external factors, including foreign invasion. A host of internal developments are equally threatening to internal stability and political order. These can cause internal strife and insurgency or can make it extremely difficult for a state to perform its basic obligations towards its citizenry. The threats that need to be addressed include economic stagnation or collapse, overpopulation, increased unemployment, acute poverty and underdevelopment, increased socio-economic inequities, ethnic or regional conflict, religious and cultural intolerance and terrorism, organized crime, drugs and environmental issues.

The state is expected to work towards the promotion of human security and human development, provision of the necessary facilities for basic education, health care, and training and skill development for professional life. The state must also provide its citizens food, shelter, drinking water, environment protection, civic facilities and an 
opportunity for improving the quality of life. This means that the state must cater to legitimate aspirations of people for economic and social progress.

The nature and dynamics of the political system and its interaction with the society are also important features of internal strengths of a state. This includes constitutionalism, participatory governance, the rule of law, non-discriminatory citizenship, and legal and administrative arrangements for protection of life and property of citizens. The state must have effective legal, administrative and judicial systems for managing and resolving various kinds of conflicts that threaten the fabric of society or state stability.

A large number of developing countries face natural disasters like earthquake, floods, epidemics, cyclones, droughts and crop failures. There are human-made disasters mainly due to poor governance, administrative negligence, corruption and internal strife that cause human sufferings and deaths in large number. The natural calamities or humaninflicted disasters result in food and water shortages, human migrations within a country or across the state-boundaries, drug problems including illegal human trafficking, environmental degradation, and proliferation of weapons, especially small arms. These negative developments pose administrative, political and economic challenges to a state which it needs to address in order to ensure internal stability and socio-political harmony. The manner in which the state handles these challenges goes a long way to ensure internal peace and stability, which in turn shapes the state's role at the global and regional levels. An effective management of these problems also helps the state to withstand external military and diplomatic pressures.

A group of the U.S.-based analysts studying new threats to human beings towards the end of the $20^{\text {th }}$ century identified several issues vital to ensuring sustainable human and social development. These included depletion of resources and overpopulation, international migrations, degradation of environment, human rights, ethnic conflicts and international financial issues, trade and economic relations. ${ }^{2}$

\section{Why the Shift in Focus}

The emphasis on the state's internal dynamics and human and societal development is not an entirely a new phenomenon. Even in the Cold War era, these issues were raised with reference to the economy, internal peace and stability and the welfare state. The focus on these issues increased in the Post-Cold War, especially from the first decade of the $21^{\text {st }}$ century and onwards. It is a five-fold focus that includes the issues of democracy, constitutionalism and human rights and human dignity, internal political harmony and stability and economic development, measures for human welfare and societal development, positive relevance of a state with the global system in terms of economic interaction, trade, investment and market for goods and services; and the state's significance for regional security and stability as well as other global campaigns for transnational challenges.

\footnotetext{
${ }^{2}$ Robert Chase, Emily Hill and Paul Kennedy (eds.), The Pivotal States: A New Framework of U.S. Policy in the Developing World (New York: W.W. Norton \& Company, 1999).
} 
There is a greater focus on internal issues and challenges that the states face because the experience of the Post-Cold War era has shown that the states can collapse or become dysfunctional because of internal factors. Most of these internal issues relate directly or indirectly to how the state deals with its citizenry. How far can the state address the socio-economic issues and deal with various aspects of human development and societal security? If the state can work towards ensuring the welfare of the common people and give them a hope for a better future within a participatory framework, there is a greater probability that societal conflict or other dissident trends can be managed effectively, if not resolved altogether. All this makes it possible for the state to cope with external pressures, become an active participant in global and regional affairs and cultivate a positive and mutually beneficial relationship with the global system.

More attention is given to non-military aspects of the state's security and especially socio-economic development. The roots of the focus on socio-economic issues and human development go back to the 1960s when the Non-aligned Movement (NAM) used to raise the issue of inequities of the international system and sufferings of the people of Asia and Africa. It was in the early 1970s that the NAM talked of New International Economic Order to focus on socio-economic inequities in the national and international systems and how the terms of trade and the working of the global economic order adversely affected the interests and welfare of the ordinary people in the developing countries, described as the Third World. The issue of economic disparities between the prosperous North and the poor South was raised even in the UN system. This not only brought to surface the inequities of the international political and economic order but also highlighted socio-economic inequities within each national system.

Though the United Nations addressed the issues of arms control and disarmament from the beginning, ${ }^{3}$ it held two special sessions of the General Assembly on Disarmament in May-June 1976 and June-July 1982 whose final declarations talked of human development issues. The UN prepared a report entitled "economic and social consequences of arms race and military expenditure" in 1962. It was revised in 1972, 1977 and 1982. The final document of the 1976 Disarmament Conference, released in 1978, noted the findings of the 1972 revised report linking disarmament with socioeconomic development. The 1972 report argued that "as long as the arms race was allowed to continue, it would aggravate world problems of development, economic imbalance and inflation pollution, scarcity of energy and raw materials, trade relations and technology, while delaying progress in areas such as health, education and housing." 4

The ideas regarding removing inequities in the international system that caused disadvantage to the developing countries and promoting socio-economic development in these countries were highlighted in the reports of two independent commissions in 1980 and 1982.The Independent Commission (1980) headed by Willy Brandt, former Chancellor of West Germany, addressed the international development affairs by

\footnotetext{
${ }^{3}$ For a review of the UN based negotiations for arms control and disarmament during 1946-71, see Disarmament: Negotiations and Treaties, 1946-71, Keesing's Research Report 7 (New York: Charles Scribner's Sons, 1972).

${ }^{4}$ The United Nations and Disarmament, 1945-1985 (New York: United Nations, 1985), p.147.
} 
acknowledging in clear term that there are glaring disparities in the standard of living between the affluent North (Western countries) and predominantly poor South (Asian and African states). It also complained about the unfavourable terms of trade for the developing countries and the transfer of resources from these countries to the affluent countries of the North. It suggested several changes in the international political and economic order to make it more equitable and participatory. It also underlined the need of allocating more resources to human and societal development. ${ }^{5}$ In 1982, another transnational Commission on Disarmament and Security Issues, headed by Olof Palme, former Prime Minister of Sweden, offered a follow-up of the Brandt Commission. It questioned the traditional notion of security that focused mainly on military security and underlined the need of paying attention to conflicts other than international and regional wars. It popularized the concept of Common Security and highlighted the need of devoting more resources to human development and welfare of the common people. Though the recommendations of these reports were not implemented these reports shifted attention from the traditional notion of security to other threats to society in individual states and the international system. These reports also criticized international financial institutions, especially the World Bank and the International Monetary Fund. ${ }^{6}$

The international concern for human development and societal security continued to increase in the 1990s. This was clearly reflected in the academic discourse as well as in the United Nations and other regional and global inter-governmental organizations or non-official think-tanks and voluntary organizations. The United Nations Development Program's Human Development Report (HDR), 1994, paid special attention to the issues that caused insecurities to human being and identified the measures for promoting human welfare and development and how to secure their future. The threats and insecurities to human-being were identified as "food insecurity, job and income insecurity, human rights violations, ethnic or religious conflicts, inequality, military spending."7 The states and the international community must work to address these insecurities, the HDR (1994) emphasized. This report drew attention to the notion Human Development Index (HDI), articulated by Dr. Mahbub-ul-Haq who was said to have benefited from the notion of human capabilities enunciated by Amartya Sen. The HDI offered an index for reviewing the standard of living, life expectancy and knowledge and education for the populace. ${ }^{8}$

The UN Millennium Summit, held on September 6-8, 2000, identified eight Millennium Development Goals (MDGs) for human and societal development during the next 15 years, 2000-2015. ${ }^{9}$ The MDG included (1) eradication of extreme hunger; (2) universal primary education; (3) gender equality and empowerment of women; (4) reduction of

\footnotetext{
${ }^{5}$ For a summary of the report of the Independent Commission headed by Willy Brandt, see Executive Intelligence Review (Vol.7 No.9, March 4, 1980), pp.29-31.

${ }^{6}$ For a review of the Commission headed by Olof Palme, see Geoffrey Wiseman, "The Palme Commission: New Thinking about Security," in Ramesh Thakur, Andres F. Cooper and John English, International Commissions and the Power of Ideas (Tokyo: United Nations University press, 2005), pp.46-75.

${ }^{7}$ UNDP Human Development Report, 1994 (New York: Oxford University Press, 1994), p. 38; see also pp.2425.

${ }^{8}$ See Mahbub-ul-Haq, Reflections on Human Development (New York: Oxford University Press, 1995).See also by the same author, The Poverty Curtain: Choices for the Third World (New York: Columbia University Press, 1976).

${ }^{9}$ See, UN General Assembly A/RES/55/2; see also www.un.org/en/events/pastevents/millennium_summit.shtml
} 
child mortality; (5) improvement of maternal health opportunities; (6) combating HIV/AIDS, Malaria and other diseases; (7) environment sustainability; and (8) work towards global partnership for promoting the development agenda. The review of the performance of the member state on these MDGs undertaken in 2015 showed that most states faltered on these items.

Despite the poor performance of the member states on the MDGs, the UN General Assembly held another summit to focus the attention of the global community on different aspects of human development and societal security. The conference, held on September 25-27, 2015, chartered a more ambitious agenda under the rubric of "Sustainable Development Goals" (SDGs) for the next 15 years, 2015-2030.The SDGs include "(1) no poverty; (2) zero hunger-elimination of hunger; (3) good health and wellbeing; (4) quality education; (5) gender equality; (6) clean water and sanitation; (7) affordable and clean energy; (8) decent work and economic growth; (9) industry, innovation and infrastructure; (10) reduced inequalities; (11) sustainable cities and communities; (12) responsible consumption and production; (13) climate action; (14) life below water; (15) life on land; (16) peace and justice, strong institutions; (17) partnerships for [achieving] the goals." ${ }^{10}$ When we examine the details of these goals, the agenda for "transforming the World" is more ambitious than the MDGs. Most of the countries would not be able to achieve these goals to the desired levels by 2030 .

The work done by the UNDP and the UN since the early 1990s has redefined the notion of national security by expanding its scope beyond military or territorial security. Given the fact that a number of states faced extreme degrees of internal violence and chaos and some states collapsed or became dysfunctional due to internal pressures and conflict, the issues of human development, societal security and provision of basic needs of people have gained importance. The underlying idea is that the state must provide a number of services and facilities to its citizenry in order to enable them to lead a stable and secure life within the framework of equal protection of law and equality of opportunities for advancing in life and securities against hunger, disease, natural disasters and a guarantee of education and skill development, health care, civic amenities, employment, human dignity and rights and a friendly environment. Other areas of human development and societal development include participatory governance that provides for equal citizenship and equal protection of law along with empowerment of the people and inclusive community development and socio-economic development.

\section{Human and Social Development in Pakistan}

There are periods in Pakistan's history when Pakistan's economic growth, industrialization and agricultural output ranged from very satisfactory to good. The data on aggregate economic development was reassuring and it engendered the hope, more than once, that Pakistan would become one of the leading economies among the developing countries. This hope did not materialize. Once again, Pakistan has registered discernible progress in some sectors of the economy during 2013-2016. The "Vision

${ }^{10}$ UN General Assembly ResolutionA/RES/70/1; see also www.un.org/sustainabledevelopment/sustainabledevelopment-goals/ 
2025" initiated by the PMLN federal government led by Nawaz Sharif in August 2014, envisages an ambitious agenda for socio-economic development and human security. It aims at elimination of electricity shortage by 2018 , increase per capita income to $\$ 4200$, a boost in industrial production and improved governance. Its major areas of focus include "developing social ad human capital, achieving sustained indigenous and inclusive growth, governance, institutional reforms and modernization of public sector energy, water and food security, private sector-led growth, developing competitive knowledge economy and modernizing transportation, infrastructure and greater regional connectivity." It also envisages a "responsive, inclusive, transparent and accountable system of governance," $"$ that seeks to ensure a secure, stable and prosperous future to the common people.

Other official statements give a very positive view of socio-economic development and that the government is striving hard for providing basic necessities of life to the ordinary people and adopting measures to overcome the problem of poverty and underdevelopment. An important social welfare programme for providing some financial support to the poorest families is the Benazir Income Support Programme that was initiated by the PPP government (2008-2013) and the PMLN government since 2013 has continued it.

Pakistan's official circles argue that Pakistan's economy is "poised for an economic takeoff" and think that Pakistan would "be among the top 25 economies of the world by 2025. In order to reach this goal, we will need to achieve an annual growth rate of over seven per cent. Though this may seem daunting with the great dividend of the CPEC in our grasp, this goal is achievable." ${ }^{2}$

The non-official experts in the fields of Political Economy and Development Economics express strong reservations on the official statements on economic growth and reject the official view of a steady economic improvement and increased welfare of the people by pointing out the wide gap between the ruler's view of Pakistan's economy and the grassroot realities. ${ }^{13}$ They also warned against the steadily increasing foreign and domestic debt on the government. In November 2016, Pakistan's foreign debt amounted to $\$ 73$ billion. ${ }^{14}$ Despite the existence of divergent perspectives on economic development, Pakistani and foreign economists agree that Pakistan has the potential to become an active and enviable economy. The challenge is how to turn the potential into a reality.

Another major challenge is that Pakistan's economy has faltered on equitable distribution of fruits of economic growth. It has not been able to adequately address the issue of socio-economic inequities among the people and regions, going back to the early years of independence. Though Pakistan gave up on the 'trickle down' approach that

\footnotetext{
${ }^{11}$ Mehtab Haider, "Vision 2025 sets per capita income at 4,200"News, August 6, 2014

${ }^{12}$ Ahsan Iqbal, "Is Pakistan Ready for a Take-off?" Express Tribune, January 20, 2016

${ }^{13}$ Farhan Bokhari, "A Baffling Economy." Dawn, June 15, 2016.See also by the same author, "Poor Food Security." Ibid, November 20, 2016.

${ }^{14}$ See the comments made on the debt issue by Dr. Ashfaque Hasan Khan and Dr. Hafiz Pasha in a news report: Shahbaz Rana, "Pakistan's External Debt likely to swell to \$110 Billion in four Years."Express Tribune,

November 13, 2016.Hafiz Pasha, "Government urged to care external debt sustainability." News, May 14, 2014.
} 
characterized economic development in the 1960s and revised its policy in the early 1970 s to give more attention to the lower strata of the society, Pakistan continued to perform poorly on 'distributive justice.' It could not formulate a long term strategy for sustainable human and social development.

Pakistan struggles hard to meet the HDI criteria. Its performance on the Millennium Development Goals (MDG) was unsatisfactory and faltered on most targets. ${ }^{15}$ Despite all the fanfare about the Vision 2025, Pakistan is not expected to meet the demands of the Sustainable Development Goals (SDG) initiated by the UN in $2015 .{ }^{16}$ The number as well as the scope of the SDG has been expanded as compared to the MDG. There is no reason that one can be optimistic about Pakistan achieving all the SDG.

The neglect of human and social development in Pakistan can be identified from the pattern of expenditure in the federal budget. The single biggest item of expenditure in the federal budget is debt repayment, followed by defence expenditure. If the expenditure on administration and law and order are also taken into account, almost 70 to 75 percent of the budget is gone. Consequently limited financial resources are available for education, health care, civic facilities including drinking water, and fighting poverty and underdevelopment. It is a common practice to cut-back on the budgeted allocations for social development or some of these allocations are either diverted to other sectors or not spent. The federal government's actual spending in the Public Sector Development Programme during the financial years 2013-14, 2014-15 and 2015-16 was less than the budgeted amount. ${ }^{17}$ The provincial allocations for education and health sector are inadequate. The government hospitals in big cities are generally overcrowded, lack sufficient facilities, including beds and medicines and medical support equipment. Most district hospitals are in poor condition and a large number of basic health units are not equipped to provide day-to-day health support to the populace.

Pakistan's Economic Survey, 2014-15, an official publication of the federal government, discloses that there are 1142 hospitals, 5438 dispensaries, 5438 basic health units and 671 maternity and child health care centres. The report does not talk about the quality of service available in these health care facilities. The same Economic Survey also says that there are 175223 doctors, 90276 nurses and 118041 hospital beds in Pakistan. ${ }^{18}$

The state owned schools suffer from shortage of facilities, including teachers and equipment. Over the years the availability of pure drinking water has become a problem which is causing a host of diseases among the people who cannot afford to purchase bottled water. The federal and provincial governments are more interested in building motorways, city bus service and other high profile construction projects rather than building hospitals, schools, providing drinking water and make food available at an affordable price. Pakistan is not a food deficit country but the people still go hungry and a

\footnotetext{
15 See, Afshan Subohi, "MDGs: Most Indicators off-track.” Dawn (Economic and Business Review Section), September 22, 2014. Mubarak Zeb Khan, "Lag in Millennium Development Goals. Ibid. February 18, 2013.

${ }^{16}$ Afshan Subohi, "Integrating SDGs in Business Model." Ibid., December 19, 2016.

${ }^{17}$ Shahbaz Rana, "Development Spending bears brunt of Deficit Reduction.” Express Tribune, July 3, 2016.

${ }^{18}$ Sehrish Wasif, "Experts call for Revamp of Health Infrastructure." Express Tribune, June 30, 2015
} 
large number of children are malnourished. One national daily editorially commented on this issue under the title of "Hunger Amidst Plenty:"

Pakistan might be one of the countries that can claim to be self-sufficient in food for many decades, yet has a very high proportion of people for whom hunger is a daily fact of life, including a large number of children suffering from physical effects of undernourishment, including stunting and wasting. ... What excuse does a country that produces enough food to feed each one of its citizen have when it comes to the fact that more than a fifth of its population is undernourished, that a tenth of its children under the age of five are suffering from wasting (reduced bodyweight compared to height), and almost half of its children are stunted due to undernourishment and hunger? ${ }^{19}$

The news items given below provide an overview of the neglect of different sectors of human and social development and the distressing state of societal conditions. The information is derived from reports and surveys by the government, non-governmental organizations and international organizations, highlighting human and societal underdevelopment and a serious human and societal insecurities. "Twenty two percent of Pakistan's population is undernourished." ${ }^{20}$ Another report mentioned that "Forty percent of Pakistan's population malnourished."21

The United Nations Education Monitoring Report, 2016 said that "Pakistan is 50+ years behind in its primary and $60+$ years behind in its secondary education targets." ${ }^{22}$ Another survey report by a Pakistani NGO suggested that "the number of out-of-school children of primary school age has reached 12.3 million, with an overall percentage of 58.88 among all primary school age children., ${ }^{23}$ Still another report said that 48 percent schools in Pakistan do not have toilets, drinking water and lack boundary walls. ${ }^{24}$ The United Kingdom based Water-Aid reported that "Pakistan is among the top 10 countries with the greatest number of people living without access to safe water." 25

A report on the gender issues described Pakistan as "second to last in Gender Equality Report." Its standing was 141 out of 142 countries studied. ${ }^{26}$

"Pakistan's Human Development Index stagnating over the last five years." ${ }^{27}$ Pakistan "stays at 146 on Human Index Development among 187 countries." ${ }^{28}$ A UNICEF report noted in 2014 that "one baby dies every three minutes in Pakistan." 29

"828 children died in drought hit Thar in three years," 2014-16. ${ }^{30}$

${ }^{19}$ Dawn, October 14, 2016

${ }^{20}$ Ibid.

${ }^{21}$ Express Tribune, October 3, 2016

${ }^{22}$ Ibid., September 7, 2016

${ }^{23}$ Ibid., July 30, 2016

${ }^{24}$ Ibid., May 25, 2016

${ }^{25}$ Dawn, March 22, 2016

${ }^{26}$ Express Tribune, October 29, 2014

${ }^{27}$ Dawn, September 20, 2014

${ }^{28}$ Ibid., July 25, 2014

${ }^{29}$ Express Tribune, September 13, 2014. 
These statements have to be read against the backdrop of the repeated statements of the political and societal leaders, including various federal and provincial governments, for eradication of poverty and under-development, increasing job opportunities and promotion of an equitable socio-economic development for securing the future of the common folks. However, these goals are not assigned a priority at the operation policy level. In addition to the scarcity of resources due to a higher priority in Pakistan for nondevelopment goals like international and domestic debt servicing, defence expenditure, the war on terrorism, and glamorous and publicity-oriented projects. The elite-focused government expenditure, corruption and nepotism have also adversely affected work on sustainable human and social development.

Another deficiency in the policies for human and societal development relates to the sharp disparities "between rural and urban Pakistan, and within different regions of the country." The UNDP has rightly pointed out that "Pakistan's institutions, incentives and laws continue to favour the rich and burden the poor." ${ }^{31}$

Politics in Pakistan is described as "detrimental to socioeconomic development and human welfare." The major political obstacles to human and social development and societal security include the "failure to evolve a sustainable agreement on the operational norms of the polity, inconclusive articulation of the relationship between Islam and the state, problem of political parties and divisive and non-aggregative politics, constitutional and political discontinuities by military intervention, an overall democracy deficit, land especially the absence of regular and noncontroversial elections.."32 There are little prospects of Pakistan overcoming poverty and underdevelopment and ensuring human and societal development in the near future. It is expected to face serious difficulties in meeting with the criteria of human and societal development set out by the HDI and SDG and their emphasis on equity and endurance.

Pakistan also faces a number of issues pertaining to climatic changes and environmental challenges that have negative impacts on human life and societal development. Pakistan's official circles claim that Pakistan emits less than one percent of "total global greenhouse gas emissions," and that Pakistan subscribes to the guidelines issued by the UN Climate Change Conference in Paris (2015) and the Global Climate Risk Index (2017), launched at Marrakech. However, Pakistan is "ranked amongst the top ten countries most vulnerable to climate change." 33

The climatic changes and especially the changes in weather pattern and global warming have a profound impact on Pakistan as it relies heavily on agriculture and natural resources. Pakistan experienced unusual floods in 2010, 2011 and 2012, causing huge human and material losses. The challenges of ensuring security of water for agriculture

\footnotetext{
${ }^{30}$ Dawn, May 3, 2016. See also Allah Bux Arisar, "Sick, Starving and Dying Children of Sindh."Ibid., December 2, 2016.

${ }^{31}$ Syed Mohammad Ali, "Inequality within our Public Agenda." Express Tribune, September 16, 2016.

${ }^{32}$ Hasan Askari Rizvi, "Political Impediments to Development." In Anita Weiss and Saba Gul Khattak (eds.), Development Challenges Confronting Pakistan (Sterling, VA: Kumarian Press, 2013), pp.81-98 (see p.97).

${ }^{33}$ Khuldune Shahid, "Pakistan not a Polluter, but Paying a Price." The Friday Times, March 31-April 6, 2017, p.5. See also Siraj Shawa, "Climate Change and Pakistan." News, November 3, 2016
} 
and human consumption, food and energy security are haunting the policy makers as well as societal leaders. Other issues that expose the inability of the federal and provincial governments to ensure human friendly environment include periodic heat waves in the summer, heavy rains and flash floods, emissions from vehicles and factories, disposal of industrial waste, smog over major cities in early winter, cleanliness of cities by proper disposal of garbage and solid state waste management. In case of some the major cities, the Pakistani government has hired some Turkish and Chinese companies for solid waste and garbage management. This is a reflection on the capacity of Pakistani government and local institutions to address the basic civic issues.

\section{Role of Social Sciences}

What is the role of Social Sciences and Social Scientists in addressing the problems and issues of societal and human development? Social scientists can play an important role in creating awareness in the society about these basic issues for a meaningful and stable life for an individual and the society. They can make the government as well as the societal leaders conscious of the growing socio-economic inequities at the global and national levels and suggest ways and means to address these problems. They can also mobilize people by writing and speaking on these issues for building pressure on the government for giving a priority-attention to these matters. Social scientists can directly influence the state policy by writing argument based articles, publishing reports on human and societal development and reviewing the government policies with a view to suggesting improvements. They can make use of the modern communication technologies for the "advocacy" of the need on the part of the government and societal leaders for assigning the highest priority to different aspects of human and societal development, especially education, health care, employment opportunities and basic civic facilities.

This is a challenging task that requires a persistent effort to highlight the problems and sufferings of the common people due to underdevelopment, poverty and socio-economic injustice. In addition to persuading the government to pay more attention to human welfare and social development, the societal leaders need to pursue these agendas through voluntary societal cooperation. The societal groups and non-governmental organizations can engage in community development in the spirit of self-help. Such a voluntary activity not only mitigates some sufferings of the people but it also builds demands on the government to be more active and cooperative for delivery of basic services to the common people. 